\title{
AN EVALUATION OF THE IMAGE OF POLAND AS A NATIONAL BRAND PERCEIVED BY YOUNG FOREIGNERS
}

\author{
Marzena Lemanowicz \\ Marzena Lemanowicz \\ Warsaw University of Life Sciences, Faculty of Economics, Poland \\ marzena_lemanowicz@sggw.pl \\ Article info \\ Paper category: Original Scientific Paper \\ Received: 5.9.2017. \\ Accepted: 10.12.2017. \\ JEL classification: M3
}




\begin{abstract}
The article provides an overview of the literature on notions including national image, national brand and national branding, then presents selected campaigns promoting Poland in the international arena. It evaluates how Poland, as a national brand, is perceived by young foreigners. Empirical studies were conducted among foreigners at the age of $20-$ 25. 103 respondents from 23 countries participated in the research. The most common associations respondents had with Poland were history, Pope John Paul II and Polish vodka. Warsaw and Krakow are definitely the most recognizable Polish cities. Many respondents expressed positive opinions about Poland's nature, landscapes, mountains and seaside. Among numerous events organized in Poland, the most well-known were the European Football Championship EURO 2012, the Woodstock Festival and Wroclaw - European Capital of Culture 2016. I believe Poland continues to be perceived through stereotypes, with associations to the Pope, vodka and religion predominating. These were enumerated as the main associations in a 2011 study and since then, despite Poland's numerous promotional work in the international arena, there has been no success in creating new associations, such as Poland being an innovative and modern country or its people being entrepreneurial, to name two.
\end{abstract}

\title{
Keywords:
}

Country image, National branding, National brand, Promotion, Poland. 


\section{INTRODUCTION}

Today, numerous countries appreciate the importance of a strong national brand as it translates into an improved international position and development. Building a strong national brand is a complex process involving various institutions and organizations. Marketing activities must be addressed to different target groups, including tourists, entrepreneurs, residents and the media. Poland has for many years been marketing internationally through the Polish Tourist Organization, the Ministry of Foreign Affairs and Polish Investment and Trade Agency. Having a strong national brand carries numerous benefits. A country is associated with certain values and symbols, which increases its international recognition and increases confidence in the state. This in turn translates into increased foreign investment, more tourist visits and talented people who want to learn and grow in the country. However, a strong national brand is built neither quickly nor easily. When looking at this issue, comparisons of national brand and traditional branding cannot be avoided. The former can be interpreted as adapting branding tools for a macroeconomic scale. This means that in addition to the branding elements such as identity and positioning, the cultural, social and political conditions in which the brand operates must also be taken into account.

The general aim of this article is to evaluate how Poland as a brand is perceived by young foreigners. Other goals include examining spontaneous associations with Poland, familiarity with Polish cities, people and events, and opinions on the subject of promotional campaigns and Poland's image. The article provides an overview of the literature on the notion of national image, national brand and national branding, and also presents selected campaigns promoting Poland on the international arena. In order to achieve these goals, empirical studies were conducted among foreigners at the age of 20-25, with 103 respondents from 23 countries participating. An internet survey was used to collect the data. The vast majority of the surveyed persons were Erasmus programme students. Selecting this particular group for research was intentional as it is the Erasmus students who are one of the target groups which Poland wants to reach with its advertising message. Polish institutions responsible for promoting Poland on the international market believe that members of this group may be good ambassadors of Poland abroad. The main hypothesis set out in this paper is that despite many advertising campaigns having been conducted, young foreigners have little knowledge about Poland.

\section{NATIONAL BRAND AS A FACTOR IN A COUNTRY'S SUCCESS}

The definition of the process of national branding and its effect, the national brand, are essential to understanding this issue, and as such are discussed widely in the subject literature. It is important to understand the essence of the process of na- 
tional branding itself in order to understand the effect it may have. As mentioned above, national branding has been further extended to include cultural, political and social perspectives in such a way that the process can be adapted to a comprehensive organizational structure-that is, the national state. In turn, the national brand has many common features with classic business branding, though we must be cognizant of the importance of the context in which it is analyzed. The mark of a nation as a tourist destination is perceived differently than the national brand as the exporter of products - a friendly country does not mean an economically viable one, and vice versa.

National branding is a strategic process. It aims to improve the image and reputation of the country through the involvement of national brand stakeholders. This process takes place on three levels (Hereinafter, 2011):

(I) Public Institutions

(II) International opinions among the public, investors, tourists and consumers

(III) Society

The levels of national branding management correspond to a variety of stakeholder groups of the national brand. Each level has its own separate functions and tasks, which ultimately work together. The first level, public institutions, coordinates activities responsible for the most important functions of the national brand-public diplomacy, tourism, foreign direct investment and exports. To address the second level, plans for communicating with and forming messages for the international public, investors, tourists and consumers should be coordinated. The communication should include elements of national identity that are relevant to the target group and the value they will gain through contact with the country. The last level involves two elements: the society in which the process of creating a national brand on a local scale should be carried out and, second, individuals involved in promoting its ideas by getting them to identify with the national brand.

A country's national brand is both a goal and a result of national branding. Strictly speaking, a national brand cannot be created - it exists as long as the country does. Through history, political and economic activity, natural and environmental value, among other factors, nations have for centuries been creating their own brand. Nonetheless, the process of national branding can change a nation's brand. A national brand, which has a lot in common with company brand, is characterized by a large number of stakeholders who have different, often contradictory, goals for the country. A conflict of interest may arise, for example, between investors and tourists. The first may look for cheap land to build factories on, while the latter are interested in quiet holiday areas and fresh air. As a concept, national brand is even more complex than brand creation done by enterprise. It does not allow for the transfer of the most well-known and most commonly used brand definition, developed by 
the American Marketing Association and adopted by Kotler (1994). This definition is limited to the material characteristics of the brand, the identity of the creator or seller, and the aspect of the brand being distinguished or standing out. Only the issue of how the brand interacts with the environment allows one to begin to understand today's national brand concept.

According to Holt (2004), brands rise to become icons through their creative interaction with the environment and the process of cultural branding. In Holt's opinion, it is this aspect of brand-environment coexistence that is best adapted to the national brand. For Lodge (2002), national brand is more than just symbolism and visualization: It is a manifestation of the collective desire to offer competitive and attractive value. Anholt (2002) maintains that national brand serves to express the country's competitive position, its strengths resulting from geographic location, economy, culture, the education system, attractiveness as a tourist destination, and export products. While both definitions underline the importance of brand for the country's competitiveness, the first one focuses on engaging the public, while the other emphasizes the strength of the brand. Another author (Allan 2004) represents the national brand as a symbolic creation that emphasizes values that are memorable, attractive, unique and important for those partaking of them, and which maintain the nation's values. Jaffe and Nebenzahl (2001) define the national brand through the definition of national branding, which seeks to create a clear, simple and distinctive idea built around emotional traits that can be illustrated verbally and visually and understood by different audiences in different situations. For a national brand to be effective, political, cultural, business and sports activities must be taken into account.

The process of creating a national brand is a relatively new area of research. The term nation branding was first used by Anholt in the late 1990s. However, as Olins (2002) points out, countries looking after how they are perceived abroad is nothing new-competition has been occurring for centuries. In addition to obvious factors such as infrastructure, taxation, education and access to cheap labor, countries also compete with their image, created through intangible values such as international significance, sporting, cultural and scientific achievements. Considered by many the father of the concept of national branding, Anholt created the hexagon model to represent the six major areas that make up the national brand: people, tourism, culture and heritage, branded exports, foreign and domestic politics and investment (Anholt 2007). 


\section{DEVELOPMENT OF THE POLSKA BRAND - KEY PREMISES OF THE COUNTRY'S BRAND BUILDING PROGRAM}

While POLAND (POLSKA, in Polish) as a brand exists, because the country lacked a cohesive image campaign and common branding concept for many years at the central level, it is not very visible, well-known or well-defined. In order to unify the strategy of building the POLSKA brand, the Polish Council of Promotion in 2013 adopted "Rules for Communicating the POLSKA Brand" (2013). This document was created on the basis of a thorough analysis of other strategic documents related to promotion and branding (among them the Strategy for the Promotion of Poland until 2015, Promoting Poland through Culture, Communication Strategy in the UK, German and French Markets, Brand Promotion in the UEFA EURO 2012TM Context). The basic conclusion drawn from the analysis of these documents, which became the basis for building the POLSKA brand, is that Poles are the brand's strongest asset; and it is through them that the brand is best reached by foreigners. Poles' numerous talents, manifest in various sectors of the economy, affect how the country is perceived. It is therefore mainly through the prism of people that POLSKA should be built. Four points have been identified to characterize the brand's identity, fashioned in colloquial, rather than official or marketing language (Rules for Communication...2013).

(I) POLSKA IS INTENSE. As people of action who take great interest in the world, Poles are continuously pressing ahead.

(II) POLSKA IS COMMITTED. Poles never have enough time for everything and are not afraid to take risks if they can gain more. As a nation, they are mild, a positive case of ADHD.

(III) POLSKA WON’T LEAVE YOU FEELING INDIFFERENT. Poles' proverbial hospitality cannot be overestimated. Few other nations in this part of the world allow newcomers to become so close. It is against our nature to leave visitors to their own devices. Poles are determined to host them as best they can, show them around and explain everything, even if they are hard pressed for time.

(IV) POLSKA KNOWS HOW TO SWIM AGAINST THE TIDE. Poles can create exceptional things even if they lack advanced infrastructure or resources in a given area. They have a knack for making something out of nothing. Poles can use their ingeniousness to create things without outside help.

The next step was to elaborate the promises the POLSKA as a brand is to convey. The slogan "Polska empowers" was chosen, and was intended to help people understand the brand and unify its communication, though it was not meant to be used in advertising campaigns. The idea was that POLSKA fuels imagination, entrepreneurship, initiative and experiences. However, the document "Rules for Communicating the POLSKA BRAND" does not lay out how the competences and responsibilities for advertising 
campaigns and events promoting Poland are to be divided. Numerous institutions and organizations participate in the process of building the POLSKA brand and producing advertising campaigns. The Polish Tourist Organization is responsible for the promotion of Polish tourism, while the promotion of the Polish economy is handled by the Polish Investment and Trade Agency together with the relevant ministries. Apart from state agendas, there are also various foundations involved, e.g. the Polish Promotional Emblem Foundation "Teraz Polska" as well as private institutions. Territorial governments of Polish cities and regions play an important role. Their marketing activities also influence how the country's image is built. It is laudable that such a multitude of institutions is involved: The country and its institutions consider promotion and branding to be an important issue. However, the sheer number of entities is at the same time to blame for the inconsistency of the message, the lack of synergies, and the organizational problems, particularly as regards the division of responsibilities (Hereźniak, 2011).

\section{SELECTED CAMPAIGNS AND ACTIVITIES PROMOTING POLAND}

In recent years, numerous marketing activities have been undertaken on foreign markets. 2014's image campaign "Polska. Spring into." well illustrates the direction "Rules for Communicating the POLAND Brand" took. The wide variety of measures undertaken within this campaign reveals a holistic approach to the promotion of Poland based on Poles. The guiding idea of the campaign was the 25 th anniversary of Poland's freedom, which coincided with its 1oth anniversary of EU membership and its $15^{\text {th }}$ anniversary of NATO membership. The campaign slogan "Polska. Spring into." was developed by Olins, a branding expert that has been involved in building Poland's brand nearly since the country began its effort.

The fact that the country's name, POLSKA, doesn't translate into foreign languages plays an important role. This name is unique and cannot be mistaken for anther (as sometimes happens with the English pronunciation of Poland and Holland). Another important element is the use of the English word spring, which can be defined as a symbol of energy and joy (the season), the accumulation of energy (the coiled object) and as a source (strength). Due to the difficulty of translation and the universal message, it was created only in English (www.msz.gov.pl). The campaign was targeted at markets in the EU, particularly the countries with the largest concentration of Polish emigrants-Great Britain, Germany, Belgium and Sweden. In London alone, 150 posters were hung, including in the underground and at Heathrow Airport. However, neither the poster nor the slogan escaped criticism. Instead of photographing Poles at the core of the entire campaign, a stock photo from the advertising agency's collections was used, while the "25 Freedom" logo in font reminiscent of Poland's Solidarity movement meant so little to Brits that its very real significance was lost on them. 
An article by Frymorgen and Kwolek (2014) cited other negative comments from the British on the ads. One individual observed that the grammar in the slogan "Polska. Spring into" makes no sense, and he didn't know what the phrase actually meant. He guessed that it was intended to encourage people to visit Poland or invest in the country. Others criticized the use of the ambiguous word spring, because it makes the message unclear. Another element of the campaign was an advertising spot featuring the photographer Chris Niedenthal. According to the Ministry of Foreign Affairs, he is an expressive person who is not only connected with Polish history but also bridges the Polish and Anglo-Saxon worlds. The spot was aired by four media giants: BBC, CNN, Eurosport and Sky News. A shorter spot shows Mr. Niedenthal walking through Warsaw, narrating as he goes. He introduces himself to the audience and talks about the pictures he shot under martial law. The narrator talks about his fascination with Poles' struggle for freedom and how they use it today. He then describes Poles as ambitious people who work hard, but with passion and dynamism, because they want to succeed. In his opinion, this is why Poland has achieved so much in 25 years and why Poles still want to change the world. At the end he says that life in Poland is much more intense, because Poland is new. Viewers then see the slogan "POLAND. Spring into New" with the website www.polska.pl. The spot emphasizes people (both younger and older) and their emotions in a variety of situations - at university, at work and on the street, all of which accords with the principles established for communicating the brand communication.

Another campaign Poland carried out on foreign markets was called "Move Your Imagination". It set out to show Poland as an intriguing place and to highlight the changes that have taken place in it over recent years. Both the slogan and the new branding served to break stereotypes about the country. The main focus was on image issues, emphasizing that Poland is a modern country and Poles have a sense of humor and don't take themselves too seriously. The promotional film "Move your imagination" took first place (there were 20 competitors) during the prestigious film festival "The Golden City Gate". The film had seven parts showing Poland through the prism of emotions experienced by foreigners visiting the country. The action of the film associated emotions and states with particular places: youth - Warsaw, love Kraków, creativity - Poznań, freedom - Gdańsk, passion - Łódź, friendship - Mazury, music - Wrocław (www.pot.gov.pl).

The "Made in Poland" slogan headlined yet another advertising campaign, this one overseen by the Ministry of Economy. It encouraged foreign investors from the Czech Republic, Germany, Ukraine, China and Russia to establish business cooperation with Polish companies. The campaign included advertising in the press, the Internet, outdoor and PR activities.

The Polish Tourist Organization conducted a large-scale campaign promoting Poland as a destination for Chinese, Indian and Japanese tourists. Advertising from Poland appeared online, on television, in the press and on outdoor advertising in 
large cities in the three countries. At the same time, research was done on what people there know about Poland, how they perceive it and whether they are interested in visiting it. It was also important to recognize what our competitive position relative to our neighbors' - Germany, the Czech Republic and Hungary. Unsurprisingly, what people in the three target countries knew about Poland is superficial and imprecise. Poland did not have a clear image, character or unique features in their eyes. The Chinese proved slightly more knowledgeable as some associated the country with Maria Skłodowska-Curie and Copernicus. World War II, holocaust, communism, Chopin's music and history were also mentioned by members of all three countries, but they knew nothing of today's Poland (www.rp.pl).

Over the last few years Poland has carried out several promotional campaigns on international markets. They corresponded to different institutions. That is why it was very important to adopt the "Rules for Communicating the POLAND Brand" in 2013 , which allowed us to develop a coherent basis for building the brand. The next part of the article presents the results of research on the awareness of the campaign and the evaluation of the POLAND brand by foreign respondents.

\section{RESEARCH RESULTS}

One hundred and three foreign respondents aged 20-25 participated in the study. Respondents represented 233 nationalities, but the majority $(72 \%)$ came from Western European countries. The study also included representatives of US, Mexico, Israel and China. One of the aims of the study was to check the spontaneous associations respondents had with Poland. Most prominent among them were vodka, Cracow, religion/Catholicism, Poles are nice people and John Paul II. Most respondents associate Poland with a variety of historical events, primarily the Second World War $(11 \%)$, the Holocaust (many mentioned Jews), the Warsaw ghetto, concentration camps (especially Auschwitz) and communism. Respondents also mentioned Lech Walesa and Solidarity. Some respondents associated Poland with modern day politics, and referred to Polish President Andrzej Duda and the President of the European Council, Donald Tusk. One respondent from Bosnia mentioned the tragic Polish plane crash at Smolensk.

Because the "Rules for Communicating the POLAND Brand" devotes so much attention to the approach that people should be the foundation of the POLAND brand, the survey sought to determine the most well-known Polish figures. They included Pope John Paul II (69\%), Maria Skłodowska-Curie (64\%), Fryderyk Chopin $(52 \%)$ and Nicolaus Copernicus $(51 \%)$ (Figure 1.$)$. 
Figure 1.: The best-known Poles according to the respondents

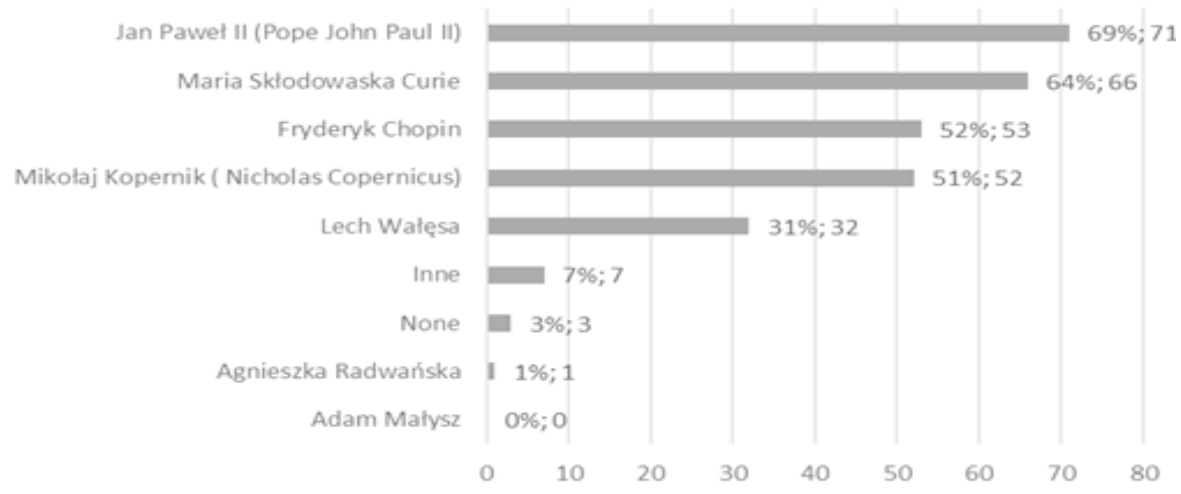

Source: Survey results.

As regards the assessment of Poles and their typical characteristics, respondents cited tradition, friendliness, religion, alcohol, and family. Negative traitsgloomy (23\%), unfriendly ( $9 \%$ ) and negative ( $8 \%$-also made the list, though they were cited less frequently.

Respondents were quite familiar with Polish cities and events taking place in the country. The most well-known cities were Warsaw and Cracow (almost all the respondents knew these cities) followed by Gdańsk (67\%) and Poznan (63\%). As for events that had taken place in Poland, the respondents were most familiar with EURO 2012, the Woodstock Festival Poland and World Youth Day in Cracow 2016. A five-point scale was used to evaluate the current image of Poland, where 1 was very bad and 5 was very good. More than $40 \%$ of the respondents rated the country a 3 , recognizing Poland's image as neutral. Almost 3०\% perceive Poland well, and 9\% very well. At the opposite end of the spectrum, 21\% of the respondents rated Poland poorly. The average rating of Poland's image among respondents was a 4 .

This article has investigated foreigners' awareness of campaigns promoting Poland internationally. To make it easier for the respondents to identify them, each slogan was accompanied by a logo, though respondents nonetheless struggled-to such an extent that over 90\% were unfamiliar with a single promotional campaign in Poland. A small proportion of respondents referred to the Move Your Imagination campaign ( $4 \%$ ) and the Poland Feel Invited campaign ( $4 \%$ ). Only one person said he recognized the campaign of Polska, Spring into New (Figure 2.). 
Figure 2.: The respondents' familiarity with campaigns promoting Poland

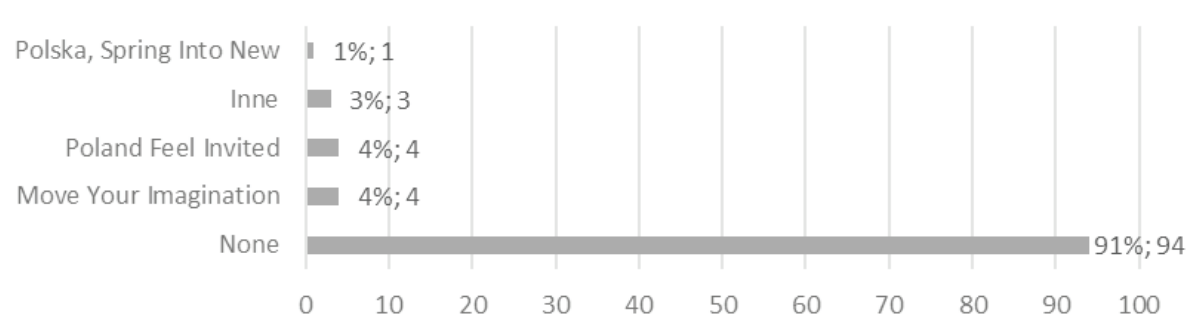

Source: Survey results.

In the light of the money poured into each of these campaigns, these results are unsatisfactory, especially as they seem to have had no effect and failed utterly to lift Poland's image.

\section{CONCLUSIONS}

Building a positive, recognizable image of a country on the international stage is no easy task. For measures to produce their intended effect, they must be sustained over a long period of time. Taking into account the results of empirical research carried out as well as the results of other surveys of Poland done by various institutions (the oldest dating to 2011), a number of similarities can be observed in foreigners' assessments of Poland's image. The results of studies on Poland's image are not very different from the results of the research I carried out, and the perception of Poland has not changed much. Still, the prevailing associations with Poland are history, John Paul II and vodka. Despite the country's redoubling its promotional efforts abroad over the last few years, new and interesting associations have not been created. Unfortunately, Poland is still perceived very stereotypically, with vodka, religion, $\mathrm{Ca}-$ tholicism and Pope John Paul II all figuring prominently in the stereotype, which continues unchanged. A positive and consistent response from respondents has been that Poles are good people. One has to admit that the young foreigners, which have participated in the survey, possessed quite a substantial amount of knowledge about famous people, places, and events organized in Poland. These findings demonstrate that the hypothesis specified in this paper has not been confirmed.

In Poland, attempts are being made to solidify the image of what Polska should convey in the international arena. Promotional campaigns aimed at specific markets and recipients, seeking to educate foreigners and encourage them to visit the country or invest, are being conducted. However, these measures do not bear real fruit and benefits. Precious few know the slogans or logos of the campaigns that have been carried out, while the perception of Poland by outsiders' remains mired in certain stereotypes. I maintain that young people should be a very important target group of 
marketing activities. The country should encourage this demographic to visit, work or study in Poland. If the government fails to take action directed at this particular group, they are not likely to take an interest in the country in the future.

Another issue concerns the consistency of advertising campaigns the country carries out abroad. Such campaigns should not correspond to different institutions, leaving the image of Poland as inchoate and incoherent, with each of the campaigns offering a different logo. Such activities certainly make it difficult to build a coherent, recognizable image of the country. Perhaps a bit of Warren Buffet's wisdom would be appropriate here: It takes 20 years to build a reputation and five minutes to ruin it. 


\section{REFERENCES}

Allan, M. (2004), Why Brand Places?, http://beyond-branding.com/Agenda_MSA_Article_Feb2004.pdf. [access: 31.07 .2017 ]

Anholt, S., Foreword to Journal of Brand Management. Journal to Brand Management, Vol. 9, No 4-5, (2002): 229-239

Anholt, Simon. Brand new justice: How branding places and products can help the developing world. Routledge, 2005 .

Frymorgen, B., Kwolek, G. (2014). Polska promuje się w Londynie. Tylko gdzie te plakaty?. http://www. $\mathrm{rmf}_{24}$.pl/fakty/polska/news-polska-promuje-sie-w-londynie-tylko-gdzie-te-plakaty,nId,14228175 [access: $31.07 \cdot 2017$ ].

Hereźniak, M., Marka narodowa. Warsaw: Polskie Wydawnictwo Ekonomiczne, 2011.

Holt, Douglas B. How brands become icons: The principles of cultural branding. Harvard Business Press, 2004 .

Jaffe, E.D., Nebenzahl, I.D. National image and Competitive Advantage. The theory and practice of country-of-origin effect. Copenhaga: Copenhagen Business School Press, 2001.

Kotler, Philip. Marketing: analiza, planowanie, wdrażanie i kontrola. Gebethner i Ska, 1994.

Ministry of International Affairs (2014). Polska. Spring into. Kampania wizerunkowa przycišga uwagę Polaków i obcokrajowców, http://www.msz.gov.pl/pl/aktualnosci/wiadomosci/polska_spring_into_ kampania_wizerunkowa_przyciaga_uwage_polakow_i_obcokrajowcow [access: 31.07.2017].

Turyści z Azji jadš do Polski. http://www.rp.pl/artykul/1165571-Turysci-z-Azji-jada-do-Polski.html\#ap-1 [access 31.07.2017]

Olins, Wally. "Branding the nation-The historical context." The journal of brand management 9, no. 4 (2002): 241-24.8

Ministry of International Affairs (2013), Rules for Communicating the POLSKA Brand, www.msz.gov.pl [access: 30.07.2017] 
